\title{
An Evaluation of the Speech Perception in Noise Test
}

\author{
Lucille P. Dickens, BA(Log) (Pretoria) \\ Callum M. Delaney, BA (Sp. and H. Therapy) (Witwatersrand) \\ Department of Logopaedics, \\ University of Cape Town, Cape Town
}

\begin{abstract}
The effects of presentation level and signal-to-babble ratio (S/B) on SPIN performance were investigatedfor eighty normal hearing listeners. $B$ oth intensity and $S / B$ had a significant effect on scores. Performance improvedat the more favourable $S / B$ regardless of presentation level, and scores were better at the lower presentation level regardless of $S / B$. Possible clinical applications of the $S P I N$ test are discussed.
\end{abstract}

\section{OPSOMMING}

Die uitwerking van aanbiedingsvlak en sein-tot-babbel-verhouding ( $S / B)$ op SPIN-toets-diskriminasietellings is ondersoek by tagtig normaalhorende luisteraars. Beide aanbiedingsvlak en $S / B$ het 'n beduidende uitwerking op diskriminasietellings. ' $n$ Hoër persentasie korrekte diskriminasie is by die meer gunstige $S / B$ verkry, ongeag die aanbiedingsvlak, en beter diskriminasietellings is by die laer aanbiedingsvlak verkry, ongeag die $S / B$. Kliniese toepassings van die SPIN-toets is bespreek.

The routine procedure in clinical speech audiometry over the past few decades has been to obtain a speech reception threshold for spondaic words and an estimation of monosyllabic discrimination ability. These measures are generally obtained in quiet conditions. In spite of the seeming popularity of this approach, much criticism has been directed against it (Dirks, Morgan and Dubno, 1982). Discrimination tests using monosyllabic words have been criticized for a number of reasons, but most frequently because test stimuli and conditions do not represent typical listening environments, and because test forms are not equivalent (Dirks and Dubno, 1984). With this in mind Kalikow, Stevens and Elliott (1977) developed the Speech Perception in Noise (SPIN) test in order to assess the understanding of speech in noise. They recognised that in speech communication adults utilize acousticphonetic and linguistic-contextual information for perception. Consequently the SPIN test comprises eight lists of 50 sentences each, where the predictability of the final target or key word of each sentence is controlled. In each list 25 items are designed to be primarily identified by the acoustic-phonetic information (low predictability (LP)) and the other 25 sentences include linguisticcontextual information which could aid identification (high predictability (HP)). The following are examples of each, "I had not thought about the growl" (LP) and "The watchdog gave a warning growl" (HP). Since everyday speech communication commonly occurs in the presence of noise, the sentences are presented in a 12-voice background babble. The sentences and babble are recorded on separate channels of audio tape, thus permitting variation of the signal-to-babble $(\mathrm{S} / \mathrm{B})$ ratio.

In constructing the test Kalikow et al. (1977) chose 250 target words from an original pool of words, with each test word presented in both an HP and an LP context in complementary lists. Form equivalence for these ten lists was investigated for a group of normal listeners at $80 \mathrm{~dB}$ SPL and at a $0 \mathrm{~dB} \mathrm{~S} / \mathrm{B}$. Two lists were discarded, and on the basis of an analysis of variance the remaining eight were considered to be equivalent for the difference score (i.e. HP - LP). While the analysis did not show similar equivalence for HP and LP scores, Kalikow et al. (1977) did no feel that this was a serious problem.

Morgan, Kamm and Velde (1981) and Bilger, Nuetzel, Rabinowitz and Rzeczkowski (1984) who also examined list equivalence did not agree with the results of Kalikow et al. (1977) and concluded that only seven of the original ten lists were equivalent. However, the experimental design of all three studies differed with respect to presentation level and S/B, subjects (normal hearing or hearing impaired) and statistical method of analysis. Thus the results of these later studies do not necessarily contradict those of Kalikow et al. (1977).

The effects of variations in presentation level, S/B, age and hearing impairment on SPIN performance have also been investigated. A consistent finding is the expected separation between the HP and LP scores, both of which improve with improved S/B ratios (Kalikow et al., 1977; Hutcherson, Dirks and Morgan, 1979; Elliott, 1979; Owen, 1981). Kalikow et al. (1977) found a slightly smaller difference score for an elderly group as compared to young subjects and Elliott (1979) found poorer HP sentence scores for 11 and 13 year old children compared to 15 and 17 year olds, which was not apparent when the sentences were presented in quiet. This finding may lend support to Owen's (1981) conclusion that differences found in difference scores are related to the audibility of the sentences rather than to the listener's use of context.

From these studies no clear pattern of results or administrative protocol emerges that might make the SPIN test clinically useful. With these issues in mind the present study was designed to examine the performance of a group of audiologically normal subjects using a locally produced recording of the test material. The object was to collect data that might provide a basis for comparison with the SPIN results of hearing impaired individuals and to identify aspects of the test that might most usefully and reliably be used in a clinical context.

\section{METHODOLOGY}

AIM

To investigate the performance of a group of normal hearing subjects on the SPIN test, and to examine the effect on performance of presentation level and signal-to-babble ratio.

\section{SUBJECTS}

Eighty young adults aged between 18 and 29 years with normal hearing sensitivity $(<15 \mathrm{~dB}$ re: ANSI 1979) at octave frequencies from 250 to $8000 \mathrm{~Hz}$ bilaterally, served as subjects. English was the native language of all subjects, and no subject had had any previous test experience with the SPIN materials.

The South African Journal of Communication Disorders, Vol. 33, 1986 


\section{INSTRUMENTATION}

The eight lists of the SPIN test were recorded by an Englishspeaking South African male. The babble was generated by recording each of six adults ( 3 males and 3 females) reading the same passage from a children's story book in an anechoic chamber, mixing these six recordings and combining two repetitions of the six-voice babble to produce the final 12-voice babble. Both the sentence and babble tracks were preceded by $1000 \mathrm{~Hz}$ calibration signals.

During the test sessions the lists were played on a two-channel (Pioneer Stereo Cassette Tape Deck - CT-F650) tape recorder. The signal and babble outputs from the tape recorder were routed to a speech audiometer (Grason-Stadler, GSI 10) where the intensity of each was determined separately before being mixed. The mixed output was delivered to the subject via a TDH-39 earphone mounted in a supra-aural cushion (MX 41/AR). The audiometers were calibrated according to ANSI 1979 standards, and prior to each test session the VU meters of each channel were adjusted according to the $1000 \mathrm{~Hz}$ calibration signal.

All testing was conducted in dual chamber sound treated test suites.

\section{PROCEDURE}

Lists were presented at two intensity levels ( 60 and $40 \mathrm{~dB} \mathrm{HL})$ and two $S / B$ ratios $(0$ and $+5 \mathrm{~dB})$. The $60 \mathrm{~dB}$ HL $0 \mathrm{~S} / \mathrm{B}$ condition was chosen to allow comparison to the Kalikow et al. (1977) study. The $40 \mathrm{~dB}$ HL level was chosen because normal to loud conversational speech falls within the 40 to $60 \mathrm{~dB}$ HL range, and because at a $40 \mathrm{~dB}$ sensation level (re: SRT) testing would be possible for a larger percentage of hearing impaired individuals than at higher levels. The $+5 \mathrm{~dB}$ S/B ratio was chosen because it is a more favourable condition as research (Pearsons, Bennett and Fidell, 1976 as cited by Dirks et al. 1982) has shown that this ratio is usually maintained for conversations in background noise.

Subjects were divided into two groups. Forty subjects were tested with the odd numbered lists, and forty subjects with the four even numbered lists, thus ensuring that complementary lists were not heard by the same person. The stimuli (signal and babble) were presented to the subject's preferred ear under four listening conditions:

$60 \mathrm{~dB}$ HL with a S/B of $+5 \mathrm{~dB}$,

$60 \mathrm{~dB}$ HL with a $\mathrm{S} / \mathrm{B}$ of $0 \mathrm{~dB}$,

$40 \mathrm{~dB}$ HL with a $S / B$ of $+5 \mathrm{~dB}$, and

$40 \mathrm{~dB} H L$ with a $S / B$ of $0 \mathrm{~dB}$;

The order of presentation remained constant, but the order of presenting the lists was varied so that each list was presented under each listening condition the same number of times. Subjects were instructed to write down the last word of each sentence.

\section{ANALYSIS OF RESULTS}

A strict scoring protocol was adopted. (Singular/plural conversions were not acceptable). Total, HP, LP and difference scores were converted into percentages. Summary statistics (means and standard deviations) were used to describe central tendencies for each of the listening conditions. Data were subjected to a two factor analysis of variance with repeated measures of both factors (Treatments-by-Treatments-by-Subjects AOV) to assess the effects of presentation level and S/B ratio.

\section{RESULTS AND DISCUSSION}

Table 1 summarizes the mean scores and standard deviations found for all the lists under the different listening conditions.
Table 1: Means and standard deviations of scores obtained under four listening conditions.

\begin{tabular}{|c|c|c|c|c|c|}
\hline \multirow{4}{*}{$\begin{array}{r}\text { Total Score } \\
\text { (HP+LP) }\end{array}$} & \multirow{4}{*}{$\begin{array}{c}\bar{X} \\
\text { SD }\end{array}$} & \multicolumn{4}{|c|}{ Listening Conditions } \\
\hline & & \multicolumn{2}{|c|}{$60 \mathrm{~dB}$} & \multicolumn{2}{|c|}{$40 \mathrm{~dB}$} \\
\hline & & 80,34 & 52,53 & 85,48 & 59,73 \\
\hline & & 8,89 & 11,77 & 6,42 & 13,04 \\
\hline \multirow[t]{2}{*}{ HP Score } & $\overline{\mathbf{X}}$ & 96,15 & 73,00 & 98,10 & 78,50 \\
\hline & SD & 5,30 & 13,07 & 3,49 & 13,94 \\
\hline \multirow[t]{2}{*}{ LP Score } & $\overline{\mathrm{X}}$ & 64,30 & 32,05 & 72,20 & 40,95 \\
\hline & SD & 14,66 & 13,51 & 11,04 & 14,86 \\
\hline \multirow{2}{*}{$\begin{array}{l}\text { Difference Score } \\
\text { (HP-LP) }\end{array}$} & $\overline{\mathrm{x}}$ & 31,90 & 40,95 & 25,90 & 37,50 \\
\hline & SD & 13,44 & 12,36 & 10,83 & 11.99 \\
\hline
\end{tabular}

The results obtained at $60 \mathrm{~dB} 0 \mathrm{~S} / \mathrm{B}$ in the present study are slightly lower than those reported by Kalikow et al. (1977), who reported the following mean values: $\mathrm{HP}=87,8 \mathrm{LP}=40,3$, and Difference $=47,4$. Means for the other conditions have not been reported in the literature. There is a difference for scores obtained at the two S/B ratios for each intensity as well as at the two presentation levels for each $\mathrm{S} / \mathrm{B}$ ratio.

Four 2-way analyses of variance with repeated measures on both factors were performed to determine whether scores (total, HP, $L P$ and difference) obtained under four listening conditions ( 60 $\mathrm{dB},+5 \mathrm{~S} / \mathrm{B}, 60 \mathrm{~dB}, 0 \mathrm{~S} / \mathrm{B}, 40 \mathrm{~dB},+5 \mathrm{~S} / \mathrm{B}$ and $40 \mathrm{~dB}, 0 \mathrm{~S} / \mathrm{B})$ differed significantly. The results of these ANOVA's showed no significant interaction between intensity level and S/B ratio. Both main effects (intensity level and $S / B$ ratio) were significant $(p<0.01)$, mean scores being better at the more favourable $S / B$ ratio regardless of $S / B$ ratio. The $F$ values obtained are summarised in Table 2. (In each case the degrees of freedom were 1,79.)

Table 2: F-values obtained in four ANOVA's to test the difference between four scores (total HP, LP and Difference) obtained under four listening conditions.

\begin{tabular}{|l|r|r|r|r|}
\hline & Total & HP & LP & \multicolumn{1}{c|}{$\begin{array}{l}\text { Diff- } \\
\text { erence }\end{array}$} \\
\hline Source & & & & \\
Intensity & $74,69^{*}$ & $14,43^{*}$ & $78,69^{*}$ & $13,40^{*}$ \\
S/B & $888,17^{*}$ & $435,08^{*}$ & $689,27^{*}$ & $54,07^{*}$ \\
$\begin{array}{l}\text { Intensity } \mathrm{x} \\
\text { x S/B }\end{array}$ & 0,94 & 2,86 & 0,13 & 1,06 \\
\hline
\end{tabular}

* p 0.01

The finding that all scores improve at the more favourable S/B ratio regardless of presentation level was to be expected and confirms results from previous studies (Hutcherson et al., 1979; Owen, 1981). An unexpected finding was that scores were better at the lower presentation level for both S/B conditions. This finding is contradictory to that of Hutcherson et al. (1979) who found little difference in scores at $50 \mathrm{~dB}$ and $80 \mathrm{~dB}$ SPL, and a definite improvement from 30 to $50 \mathrm{~dB}$ SPL. Since the order of testing under the four listening conditions was held constant it may be postulated that a learning effect produced this result. However, in such a case less of a difference would be expected between the $60 / 40 \mathrm{~dB} 0 \mathrm{~S} / \mathrm{B}$ conditions than the $+5 \mathrm{~S} / \mathrm{B}$ conditions, but examination of the results indicates that the difference is of equal magnitude. A similar intensity effect appears to be present in data reported for thee normal hearing subjects for words from NU \#6 lists presented in SPIN background babble (Dirks et al., 1982). 
Taken together these results may suggest that there is an optimal presentation level for discrimination of speech in noise, and that an increase or decrease in this level will result in a deterioration of performance. This level may correspond to that of conversational speech ( $40 \mathrm{~dB} \mathrm{HL})$. The effect should be more thoroughly explored - for both the normal hearing population and those with sensorineural hearing losses. It would be interesting to determine how, for example, individuals with cochlear losses and concomitant intolerance for loud sounds would perform.

The immediate clinical implication of these results is that the SPIN test should not be administered under listening conditions for which normative data is unavailable. Regardless of the measure used, both intensity and S/B affect performance. Consequently no generalizations about scores can be made. The present findings provide a means for comparing the performance of hearing impaired individuals with that of normal listeners. For such a purpose it is suggested that the $40 \mathrm{~dB}+5 \mathrm{~S} / \mathrm{B}$ protocol is adopted. At the $40 \mathrm{dBSL}$ reSRT presentation level testing is likely to be possible for the majority of hearing impaired listeners, and the $+5 \mathrm{~dB}$ S/B provides the most well defined normal performance. The good HP scores and the relatively high LP scores would allow measurement of the poorer performance by the hearing-impaired individual over a wider range than would be possible under the other three conditions. The HP and LP scores provide two sources of information. They provide an indication of performance that can be compared with normal performance. In addition the relationship between the HP and LP scores for an individual provide an indication of the extent to which he is taking advantage of sentence context, and this has important therapeutic implications. However, this relationship is only meaningful in the context of the normal HP and. LP scores.

Considering that noise has a differential effect on individuals even with similar audiometric configurations and degree of loss (Plomp and Mimpen, 1979), determination of performance functions for various $\mathrm{S} / \mathrm{B}$ ratios and intensity levels would give the best estimate of ability to understand speech at suprathreshold levels. However, in its present form the SPIN test would not be a cost effective or practical method for this purpose, being too time-consuming and fatiguing.

In conclusion it is suggested that the SPIN test be administered at the $40 \mathrm{~dB}+5 \mathrm{~S} / \mathrm{B}$ level in order to obtain comparative and rehabilitative information. Any diagnostic application of the SPIN test among hearing-impaired individuals requires further research.

\section{REFERENCES}

Bilger, R.C., Nuetzel, J.M., Rabinowitz, W.M., and Rzeczkowski, C. Standardization of a Test of Speech Perception in Noise. $J$. Speech Hear. Res., 27, 32-48. 1984.

Dirks, D.D., Morgan, D.E., and Dubno, J.R. A Procedure for Quantifying the Effects of Noise on Speech Recognition. $J$. Speech Hear. Disord, 47, 114-123, 1982.

Dirks, D.D., and Dubno, J.R. Speech Audiometry. In J. Jerger (ed.) Hearing Disorders in Adults: Current Trends, San Diego: College-Hill Press, 1984.

Elliott, L.L. Performance of Children Aged 9 to 17 Years on a Test of Speech Intelligibility in Noise Using Sentence Material with Controlled Word Predictability. J. Acous. Soc., Am., 66, 651-653, 1979.

Hutcherson, R.W., Dirks, D.D.,and Morgan, D.E. Evaluation of the Speech Perception in Noise (SPIN) Test. Otolaryngol. Head Neck Surg., 87, 239-245, 1979.

Kalikow, D.N., Stevens, K.N., and Elliott, L.L. Development of a Test of Speech Intelligibility in Noise Using Sentence Materials with Controlled Word Predictability. J. Acoust. Soc., Am., 61, 1337-1351, 1977.

Morgan, D.E., Kamm, C.A., and Velde, T.M. Form Equivalence of the Speech Perception in Noise (SPIN) Test. J.Acoust.Soc., Am., 69, 1791-1798, 1981.

Owen, J.H. Influence of Acoustical and Linguistic Factors on the SPIN Test Difference Score. J. Acoust. Soc. Am., 70, 678-682, 1982.

Plomp, R., and Mimpen, A.R. Speech Reception Threshold for Sentences as a Function of Age and Noise Level. J. Acoust. Soc. Am., 66, 1333-1342, 1979. 


\section{INFORMATION FOR CONTRIBUTORS}

The South African Journal of Communication Disorders publishes reports and papers concerned with research, or critically evaluative theoretical, or therapeutic issues dealing with disorders of speech, voice, hearing or language, or on aspects of the processes underlying these.

The South African Joumal of Communication Disorders will not accept material which has been published elsewhere or that is currently under review by other publications.

All contributions are reviewed by at least two consultants who are not provided with author identification.

Form of Manuscript. Authors should submit four neatly typewritten manuscripts in triple spacing with wide margins which should not exceed much more than 25 pages. Each page should be numbered. The first page of two copies should contain the title of the article, name of author/s, highest degree and address or institutional affiliation. The first page of the remaining two copies should contain only the title of the article. The second page of all copies should contain only an abstract (100 words) which should be provided in both English and Afrikaans. Afrikaans abstracts will be provided for overseas contributors. All paragraphs should start at the left margin and not be indented.

Major headings, where applicable, should be in the order of METHOD, RESULTS, DISCUSSION, CONCLUSION, ACKNOWLEDGEMENTS and REFERENCES.

Tables and Figures should be prepared on separate sheets (one per table/figure). Figures, graphs and line drawings must be originals, in black ink on good quality white paper. Lettering appearing on these should be uniform and professionally done, bearing in mind that such lettering should be legible after a $50 \%$ reduction in printing. On no account should lettering be typewritten on the illustration. Any explanation or legend should not be included in the illustration but should appear below it. The titles of tables and figures should be concise but explanatory. The title of tables appears above, and of figures below. Tables and figures should be numbered in order of appearance (with Arabic numerals). The amount of tabular and illustrative material allowed will be at the discretion of the Editor (usually not more than 6).

References. References should be cited in the text by surname of the author and date, e.g. Van Riper (1971). Where there are more than two authors, $e t a l$. after the first author will suffice. The names of all authors should appear in the Reference List. References should be listed alphabetically in triple-spacing at the end of the article. For acceptable abbreviations of names of journals, consult the fourth issue (October) of DSH ABSTRACTS or The World List of Scientific Periodicals. The number of references used should not exceed much more than 20.

Note the following examples:

Locke, J.L. Clinical Psychology: The Explanation and Treatment of Speech Sound Disorders. J. Speech Hear. Disord., 48, 339-341, 1983.

Penrod, J.P. Speech Discrimination Testing. In J. Katz (Ed.) Handbook of Clinical Audiology, 3rd ed., Baltimore: Williams \& Wilkins, 1985

Van Riper, C. The Nature of Stuttering. Englewood Cliffs, New Jersey: Prentice-Hall, 1971.

Proofs. Galley proofs will be sent to the author wherever possible. Corrections other than typographical errors will be charged to the author.

Reprints. 10 reprints without covers will be provided free of charge. All manuscripts and correspondence should be addressed to: The Editor.

South African Joumal of Communication Disorders,

South African Speech and Hearing Association P.O. Box 31782, Braamfontein 2017, South Africa.

\section{INLIGTING VIR BYDRAERS}

Die Suid-Afrikaanse Tydskrif vir Kommunikasieafwykings publiseer verslae en artikels oor navorsing, of krities evaluerende artikels oor die teoretiese of terapeutiese aspekte van spraak-, stem-, gehoor- of taalafwykings, of oor aspekte van die prosesse onderliggend aan hierdie afwykings.

Die Suid-Afrikaanse Tydskrif vir Kommunikasieafwykings sal nie materiaál aanvaar wat reeds elders gepubliseer is, of wat tans deur ander publikasies oorweeg word nié.

Alle bydraes word deur minstens twee konsultante nagegaan wat nie ingelig is oor die identiteit van die skrywer nie.

Formaat van die Manuskrip. Skrywers moet vier netjies getikte manuskripte in 3-spasiëring en met breë kantlyn indien, en dit moet nie veel langer as 25 bladsye wees nie. Elke bladsy moet genommer wees.

Op die eerste bladsy van 2 afskrifte moet die titel van die artikel, die naam van die skrywer/s, die hoogste graad behaal en die adres of naam van hulle betrokke instansie verskyn. Op die eerste bladsy van die oorblywende twee afskrifte moet slegs die titel van die artikel verskyn. Die tweede bladsy van alle afskrifte moet slegs 'n opsomming ( 100 woorde) in beide Engels en Afrikaans bevat. Afrikaanse opsommings sal vir buitelandse bydraers voorsien word: Alle paragrawe moet teenaan die linkerkantlyn begin word en moet nie ingekeep word nie.

Hoofopskrifte moet, waar dit van toepassing is, in die volgende volgorde wees: METODE, RESULTATE, BESPREKING, GEVOLGTREKKING, ERKENNINGS en VERWYSINGS.

Tabelle en Figure moet op afsonderlike bladsye verskyn (een bladsy per tabeVillustrasie). Figure, grafieke en lyntekeninge moet oorspronklike weergawes wees en moet in swart ink op wit papier van 'n hoë gehalte gedoen word.

Letterwerk wat hierop verskyn moet eenvormig wees, professioneel gedoen word en daar moet in gedagte gehou word dat dit leesbaar moet wees na 'n 50\%-verkleining in drukwerk. Letterwerk by die illustrasie moet onder geen omstandighede getik word nie. Verkla- rings of omskrywings moet nie in die illustrasie nie, maar daaronder verskyn. Die byskrifte van tabelle moet bo-aan verskyn en dié van figure onderaan. Tabelle en figure moet in die volgorde waarin hulle verskyn, genommer word (met Arabiese syfers). Die hoeveelheid materiaal in die vorm van tabelle en illustrasies wat toegelaat word, word deur die redakteur bepaal (gewoonlik nie meer as 6 nie). Verwysings. Verwysings in die teks moet voorsien word van die skrywer se van en die datum, bv. Van Riper (1971). Waar daar meer as twee skrywers is, sal et al. na die eerste skrywer voldoende wees. Die name van alle skrywers moet in die Verwysingslys verskyn. Verwysings moet alfabeties in 3-spasiëring aan die einde van die artikel gerangskik, word. Vir die aanvaarde afkortings van tydskrifte se titels, raadpleeg die vierde uitgawe (Oktober) van $D S H$ ABSTRACTS of The World List of Scientific Periodicals. Die getal verwysings wat gebruik is, moet nie veel meer as 20 wees nie. Let op die volgende voorbeelde:

Locke, J.L. Clinical Phonology: The Explanation and Treatment of Speech Sound Disorders. J. Speech Hear. Disord, 48, 339-341, 1983.

Penrod, J.P. Speech Discrimination Testing. In J. Katz (Ed.) Handbook of Clinical Audiology, 3de ed., Baltimore: Williams \& Wilkins, 1985.

Van Riper, C. The Nature of Stuttering. Englewood Cliffs, New Jersey: Prentice Hall, 1971.

Proewe. Galeiproewe sal waar moontlik aan die skrywer gestuur word. Die onkoste van veranderings, behalwe tipografiese foute, sal deur die skrywer self gedra moet word.

Herdrikke. 10 herdrukke sonder omslae sal gratis verskaf word. Alle manuskripte en korrespondensie moet gerig word aan: Die Redakteur,

Die Suid-Afrikaanse Tydskrif vir Kommunikasieafwykings.

Die Suid-Afrikaanse Vereniging vir Spraak- en Gehoorheelkunde, Posbus 31782,

Braamfontein 2017, Suid-Afrka. 